\section{Biliary tract}

\section{OXIII/1 691}

PROBABIITY OF DEVELOPING GALLSTONES AND RELATED RISK FACTORS IN 400 CIRRHOTICS.

D. Conte, D. Barisani, M. Fraquelli, P. Casarin 1, P. Bodini'2, M. Borzio ${ }^{3}$, G.P. Aimo 4 , C. Mandelli.

Istituto di Scienze Mediche and ${ }^{3}$ Ospedale Fatebenefratelli- Milano, and Ospedali di ${ }^{1}$ Sacile, ${ }^{2}$ Cremona, and ${ }^{4}$ Sald - Italy.

Background Several studies have described an increased prevalence of gallstones (GS) in cirthosis; furthermore, an annual incidence of $2.6 \%$ (1) and a global cumulative incidence of 5.5 cases/100 patients/year have recently (2) been reported.

Aim To estimate the probability of GS development and related risk factors in 400 patients with cirrhosis of different etiology, GS free at enrollment

Patients 400 patients ( 257 men and 143 women; mean age $58 \pm$ SD $10 \mathrm{yr}$, and $61 \pm$ SD 10 yr., respectively) with cirrhosis related to alcohol abuse ( $n=169)$ $\mathrm{HBV}$ or HCV chronic infection ( $n=138$ ), HBV or HCV chronic infection and alcohol abuse $(n=50)$ and miscellameous ( $n=43$ ). At enrollment 231 patients were in Child's A class, 130 in B and 39 in C. Follow up consisted of clinical examination, liver function test and ultrasound liver scan (US) every six months. Diagnosis of GS was based on consistent US findings or emergency cholecystectomy for GS.

Methods The cumulative probability of developing GS was estimated by the Kaplan-Meier method. Possible risk factors for GS were studied by logistic regression analysis which included the following variables: sex, age, body mass index (BMI), alcohol intake, Child's class, etiology of cirrhosis, HBsAg albumin, bilirubin, AST, ALT, rGT, alkaline phosphatase, cholesterol, triglycerides.

Results The median duration of follow up was $48 \mathrm{mo}$. (range 6-232). 94 patients (23.5\%) developed GS. The cumulative probability of developing GS according to years of follow up is given in the table.

$\begin{array}{cccccc}\text { Follow up (yr) } & \mathbf{0} & \mathbf{2} & \mathbf{4} & \mathbf{6} & \mathbf{8} \\ \text { Patients at risk (n) } & \mathbf{4 0 0} & 366 & 256 & 156 & 86 \\ \text { Probability (\%) } & - & \mathbf{5} & \mathbf{1 5} & \mathbf{2 4} & \mathbf{3 8}\end{array}$

The risk of developing GS increased significantly with BMI ( $p<.001$, odds ratio 1.05 ) and was significantly higher in women than men ( $p<.001$, odds ratio 2.16) and in Child's class $B / C$ than $A$ ( $p<.001$ in both cases with odds ratio of 2.84 and 5.59 respectively).

Conclusions In terms of both prevalence (3) and incidence, cholelithiasis represents a major problem in cirrhosis and an accurate follow up of cirrhotic patients, GS free at enrollment, is mandatory.

1) Acalovschi M. et al. Am J Gastroenterol 1991; 86: 1179-81.2) Sheen I S et al. Hepatology 1989; 9: 538-40.3) Conte et al. Am J Gastroenterol; 1991; 86: 1629-32.

\section{OXIII/3 645}

INTRACELLULAR SECOND MESSENGERS RESTORE THE IMPAIRED CONTRACTILITY OF HUMAN GALLBLADDERS WITH CHOLESTEROL STONES. P.R.Yu, P. Biancani and L.Behar, Department of Medicine, Rhode Island Hospital, Brown University Medical School, Providence, R.I, U.S.A

Previous studies have shown that human gallbladders with cholestero stones (CS) have a weak contraction in response to the octapeptide of cholecystokinin (CCK-8). In contrast, gallbladders with pigment stones (PS) appear to have a normal response. The CCK induced gallbladder muscle contraction is mediated by two pathways: 1) the action of low concentrations of $\operatorname{CCK}\left(10^{-13} \mathrm{M}\right)$ is mediated by inositol trisphosphate diacylglycerol (DAG)-protein kinase C (PKC) pathway; 2 ) high concentrations of CCK $\left(10^{-8} \mathrm{M}\right)$ also act through IP-3 and intracellular calcium which then activates the calmodulin (CM) and light myosin chain kinase pathway. The aim of these studies was to examine the functional integrity of the intracellular pathways that mediate CCK induced contraction in muscle cells from specimens with CS. Sixteen gallbladders with cholesterol and fourteen with pigment stones were included in these studies. All patients had the gallbladders removed electively and none had a history of acute cholecystitis. Studies were performed in enzymatically digested intact or permeabilized smooth muscle cells. Muscle cells were permeabilized by exposure to saponin ( $75 \mu \mathrm{g} / \mathrm{kg}$ for 4 minutes). Doseresponse studies with CCK-8 $\left(10^{-13}\right.$ to $\left.10^{-7} \mathrm{M}\right)$ showed that the contraction of muscle cells from gallbladders with PS was greater than that of muscle cells from specimens with $C S(p<0.05)$. Dose-response studies with IP-3 $\left(10^{-10}-10^{-5} \mathrm{M}\right)$, DAG $\left(10^{-13}-10^{-7} \mathrm{M}\right)$ and $\mathrm{CM}\left(10^{-13}\right.$ to $10^{-5}$, activated with $1.32 \mu \mathrm{M}$ of calcium, increased the contractility of muscle cells from cholesterol stones compared to the contraction induced by CCK $(p<0.05)$. In contrast, there was no difference between the contraction induced by the second messengers and by $\mathrm{CCK}$ in muscle cells from gallbladders with PS. There was also no difference between the contraction of muscle cells from specimens with CS and from specimens with PS in response to IP-3, DAG and CM. The CCK induced contraction appears to be mediated by $\mathrm{Gi} 3$ protein since it was almost completely blocked by a specific antibody against the ai3 subunit. GTPYS $\left(10^{-9}-10^{-4}\right.$ $M)$, the non-hydrolyzable GTP, also increased the contractility of the muscle cells from gallbladders with CS to levels similar to those from specimens with PS. It is concluded that the contractility of muscle cells from specimens with CS is restored by activating the postmembrane pathways and the muscle defect may be due to abnormal receptor function and/or abnormal interaction between receptors and $G$ proteins.

\section{ACUIS \& CRRONIC BFTECTS OF ORAL CBOLBSTYYRAMINE ON GALLBIADDER \& ANTRAR MOTILITY IN OBESE a IEAN INDIVIDUALS. P. Poxtipcasa A.Di Ciaula, v.Palnieri, G.Palasciano, Institute of clinica Modica I, University Modical school, Bari, Italy.}

Gallbladder (GB) stasis is frequent in obeses who are at increased risk for crystals/gallstone formation. We showed that cholestyramine $(\mathrm{CH})$ enhances cholecystokinin release and postprandial $G B$ evacuation in healthy subjects and ameliorate GB hypomotility in gallatone patients (Gastro 1992, 102.633 and $102: 1329$ )

Hence, we studied $\mathrm{CH}$-induced $\mathrm{GB}$ emptying in obeses and controls, also measuring gastric motor function which can be affected by CCX levels.

METHODS: Basal/residual GB volumes \& antrum areas were assessed by sonography every 5-15 min during $2 \mathrm{hr}$ in 12 obeses (2M,10F, age $37 \mathrm{Yr} \pm S E M 5$, BMI $39 \pm 2 \mathrm{~kg} / \mathrm{m} 2$ ) and 7 lean volunteers

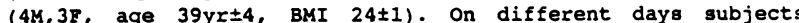
ingested water $200 \mathrm{~mL}$ test meal alone (2 egg yolks). or in combination to $\mathrm{CH} 4 \mathrm{~g}$. Tests were repeated after 1 mo in obeses on $\mathrm{CH} 4 \mathrm{~g}$ ( 3 times weekly). REsulrs (meantSE)

\begin{tabular}{|c|c|c|c|c|}
\hline D volw & maxl & $\operatorname{mea} 1+\mathrm{Cr} 4 \mathrm{~g}$ & meal & meal+ch4g \\
\hline $\mathrm{sal}, \mathrm{mL}$ & $18.3 \pm 1.8$ & $18.0 \pm 1.2$ & $39.4 \pm 6.9^{*}$ & $39.8 \pm 4.6$ \\
\hline sidual, mL & $4.4 \pm 0.6$ & $0.9 \pm 0.3^{\circ}$ & $12.3 \pm 1.8^{\star}$ & $5.0 \pm 0.7^{\circ}$ \\
\hline$c_{-}$ & $-459: \pm 30$ & $609 \pm 82^{\circ}$ & $319 \pm 42^{*}$ & $470 \pm 37^{\circ}$ \\
\hline 12 , min & $22 \pm 2$ & $21 \pm 2$ & $33 \pm 2^{*}$ & $25 \pm 2^{\circ}$ \\
\hline ITRUM & meal & -eal+CB $4 \mathrm{~g}$ & meal & $\operatorname{mea} 1+\mathrm{CB} 4 \mathrm{~g}$ \\
\hline $\mathrm{A}, \mathrm{cm} 2$ & $11.0 \pm 1.0$ & $10.2 \pm 0.8$ & $12.6 \pm 1.2$ & $11.7 \pm 0.8$ \\
\hline & $504 \pm 42$ & $123 \pm 101^{\circ}$ & $365 \pm 40$ * & $299 \pm 66$ \\
\hline
\end{tabular}

AUC, area under emptying curve; $t / 2$, half-emptying time; MPA, maximal postprandial area; $0.0001<p<0.05$ vs meal of lean $(*)$ and vs each prior meal (․).

one mo. after postprandial $\mathrm{CH}$ therapy in obeses, meal and meal+CH-induced $G B$ emptying were maintained. Gastric emptying increased after meal (AUC 506 \pm 50 ) and meal+CH $(495 \pm 28$ ) ( $p<0.05$ s prior meal+CH).

CONCLUSIONS: a moderate dose of $\mathrm{CH}$ after a liquid test meal: (i) in healthy subjects enhances GB- but reduces antral emptying; (ii) in obeses improves the GB motility defect by enhancing speed \& magnitude of emptying both acutely and after chronic therapy, when antral emptying also ameliorateg.

\section{OXIII/4 663}

CLONING AND FUNCTIONAL EXPRESSION OP A CCX-B RECEPTOR PROM GUINEA PIG GALLBLADDER Branch, NIDDK, National Institutes of Bealth, Bethesda, MD 20892

The contractile response to cholecystokinin (CCR) on isolated smooth muscle cells may be mediated by two distinct $\mathrm{CCR}$ receptor subtypes, one $\mathrm{CCK}$ preferring and the other gastrin preferring. We have recently isolated a CDNA from guinea pig gallbladder with sequence homology to the $C_{C} R_{A}$ receptor subtype. Its receptor expression pharmacology is consistent with the physiological data for a CCR preferring consistent.

We screened a guinea pig gallbladder CDNA library with a $32 \mathrm{p}$ labelled, rat $C_{C K_{B}}$ receptor CDNA coding sequence probe in order to identify a second $C C R$ receptor subtype with gastrin preferring pharmacology. The two longest CDNA clones identified $(=2.9 \mathrm{~kb}$ insert $)$ contained a single long reading frame encoding a 453 amino acid protein with 908 homology with the rat $\mathrm{CCK}_{B}$ receptor and a calculated molecular weight of $48.2 \mathrm{kDa}$. Hydropathy analys is indicates seven regions of hydrophobic residues corresponding to putative transmembrane domains expected for members of the gutatein-coupled superfamily of receptors. The sequence allows for three potential N-linked glycosilation sites in the extracellular amino terminus. Expression analysis of the extracellular amino terminus. Expresion analysis of vector pCDL-SR-alpha and transiently expressed in COS-7 cells showed specific and saturable binding of 125I-BoltonHunter labelled $\mathrm{CCK}-9$ (125I-BH-CCR). $\mathrm{CCK}-8$ and gastrin 17-1 inhibited binding with nearly equal potency $\left(\mathrm{IC}_{50}=10 \mathrm{nM}\right)$ and was nearly 100 fold more potent than the $\mathrm{CCK}_{\mathrm{A}}$ receptor antagonist $I 364,718$. These results are similar to results seen for native $\operatorname{Cck}$ receptors in guinea pig brain and gastric glands and is consistent with $C_{C K}$ receptor subtype. Conclusion: These studies demonstrate that in addition to a $\mathrm{CK}_{\mathrm{A}}$ receptor subtype, the guinea pig gallbladde expresses a second $C C R$ receptor with a typical $C C_{B}$ receptor subtype pharmacology. 


\section{OXIII/5 705}



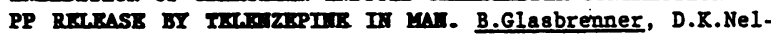
son, G.Dahmen, R.L.Riepl*, P.Malfertheiner, G.Adler. Dept. of Internal Medícine, Oniversity of Olm ${ }^{\prime}$ and Medizinische Klinitk Innenstadt*, Oniversity, of Munich, Germany.

Nonselective muscarinic receptor blockade with atropine inbibits CCR-induced gallbladder(GB) contraction and pancreatic polypeptide(PP) release in man. Studies using pirenzepine fielded conflicting results on the involvement of muscarinic receptor subtypes. We therefore-investigated of muscarinic receptor subtypes. We therefore investigated caerulein-induced GB-contraction: and PP release

LETHODS:Seven healthy male medical students volunteered for two series of experiments ( $4-7$ days apart). $T(1.5 \mathrm{mg} / \mathrm{h}$ ) or placebo were-infused $i . v$. over $2 \mathrm{~h}$ (randomized,doubleDIInd). GB volume was assessed by ultrasonography before and during $i_{-7 \ldots}$..infusion of two consecutive doses of caerulein (I0ng/ $/ \mathrm{kg} / \mathrm{h}$ over $45 \mathrm{~min}$, then $/ 30 \mathrm{ng} / \mathrm{kg} / \mathrm{h}$ over $45 \mathrm{~min}$ ). CCK and PP.plasma concentrațions were measured at 15 time intervals by highly specific radioimminoessays.

RESUlTS: Basal GB volume was $29 \pm 4 \mathrm{~cm}^{3}$ and was not altered by $T$ infusion ( $30 \mathrm{~min}$. ) before caerulein(C)-stimulation. Infusion of $C$ caused $G B$ volume reduction to: $36 \pm 8 \%$. of initial volume at $75 \mathrm{~min}$ (end of $10 \mathrm{w}$-dose $C$ ) and to $2+1 \mathrm{~T}$ at $120 \mathrm{~min}$ (end of high-dose C). I inhibited integrated GB contraction (areas above the curves) from $3865 \pm 1083$ to $1098 \pm 1001(p<0.001)$. With regard to the different doses of $c, T$ inhibited low-dose response by $78 \mathrm{~T}(p<0.001)$ and highdose respose by $25 z$ (n.s.). Basal and "stimulated" (due to $C$ infusion) CCK plasma levels were not different on both days. PP plasma levels' were increased by $C$ infusion from $79+10 \mathrm{pg} / \mathrm{ml}$, to $104+20 \mathrm{pg} / \mathrm{ml}$ (n.s.). at $75 \mathrm{~min}$ and to $193+33$ $\mathrm{pg} / \mathrm{ml}(\mathrm{p}<0.005)$ at 120 min . T completely suppressed stimulation of PP release, and PP plasma levels even fell below basal (from $86 \pm 7 \mathrm{pg} / \mathrm{ml}$ to $57 \pm 4 \mathrm{pg} / \mathrm{ml}$ at $120 \mathrm{~min} ; \mathrm{p}<0.01$ ).

CONCLOSIONS: Selective Ml-receptor blockade inhibits caerulein-induced GB contraction in man, especially during stimulation with a "physiologic" dose. These data support the hrpothesis that in-muscarintc receptors are Involved in the anticholinerglc inhibition of $C C R$-induced $G B$ contraction in man. We furthermore have confirmed that an intact cholinergic innervation via MI-receptors is crucial for the stimulation of $\mathrm{PP}$ release.
OXIII/7 648

EFFECTS OF ALCOHOL ON GALLBLADDER EMPTYING IN RESPONSE TO A NORMAL MEAL IN HEALTHY SUBJECTS. P. Mambrini, M. Perreard, A. Gerolami, INSERM - U260, Faculté de Médecine, Marseille, FRANCE.

Chronic alcoholism may be a risk factor for pigment cholelithiasis, even in the absence of cirrhosis. In view of the role played by gallbladder (GB) stasis in the pathogenesis of gallstones, the effect of alcohol on GB motility has been investigated. Previous studies carryed out under non physiological conditions have yielded conflicting results. The purpose of this study was to evaluate the effect of moderate doses of alcohol, ingested during-a normal meal, on GB emptying. Methods : GB emptying was studied, using real time sonography in 11 non alcoholic caucasian healthy men (mean age : $23 \pm 2 \mathrm{yr}$ ). GB volume was measured before the test meal (ingestion time $15 \mathrm{mn}$ ) after a 6 hours fast and every 15.min for $105 \mathrm{~min}$. Three different tests were performed in each subject. 1) Standard solid test meal (carbohydrate $75 \mathrm{~g}$; fat $55 \mathrm{~g}$; proteine $55 \mathrm{~g}$ ) with $400 \mathrm{mr}$ of water $(900 \mathrm{Kcal})$. 2) The same test meal with $400 \mathrm{ml}$ of red wine ( $38 \mathrm{~g}$ of ethanol; $1166 \mathrm{Kcal}) .3$ ) Test meal with $400 \mathrm{ml}$ of water and $66 \mathrm{~g}$ of carbohydrate $(1166 \mathrm{Kcal}) . \mathrm{GB}$ volumes were calculated according to the method of Dodds et al.. Data were expressed in volume (ml) and in percentage of the initial fasting volume and were analyzed by the non parametric test of Kruskall-Wallis and by analysis of variance. Results : The residual GB volume was $59 \%$ at $15 \mathrm{~min}, 44 \%$ at $45 \mathrm{~min}$, $30 \%$ at $75 \mathrm{~min}, 19 \%$ at $105 \mathrm{~min}$ with water and $54 \%$ at $15 \mathrm{~min}, 51 \%$ at 45 $\mathrm{min}, 42 \%$ at $75 \mathrm{~min}, 31 \%$ at $105 \mathrm{~min}$ with water and sugar. No significant different was noted between these two tests. In contrast, GB volume did not decrease significantly after alcohol ingestion. The residual $G B$ volume was $91 \%$ at $15 \mathrm{~min}, 87 \%$ at $45 \mathrm{~min}, 86 \%$ at $75 \mathrm{~min}$ and $78 \%$ at $105 \mathrm{~min}$. Conclusion : Ingestion of alcohol during a normal meal inhibits GB emptying a least for $105 \mathrm{~min}$. Such an inhibition could facilitate pigment gallstones formation in alcohol consumers.

\section{OXIII/6 693}

PROMOTION OF GALLBLADDER EMPTYING AND CHOLECYSTOKININ RELEASE BY RAPID INTRAVENOUS ADMINISTRATION OF AMINO ACIDS. G Zoli, A Ballinger, J Healy, LJD O'Donnell, ML Clark, MJG Farthing. Depts. Gastroenterology \& Radiology, St Bartholomew's Hospital, London, UK \& I Medical Pathology, University of Bologna, Italy.

Patients receiving total intravenous nutrition have inert gallbladders and as a consequence develop gallbladder sludge and gallstones; these can be prevented by enhancing gallbladder emptying. We have explored the efficacy of rapid infusions of intravenous amino acids (IVAAs) in stimulating colecystokinin (CCK) release and gallbladder contraction, and determined the minimum infusion regimen capable of producing gallbladder emptying.

Eight healthy fasted subjects on four mornings received in random order four different infusion regimens of an IVAA mixture (Synthamin $14,85 /$ amino acids). Gallbladder volumes were determined by ultrasonography before and at $5 \mathrm{~min}$ intervals for $60 \mathrm{~min}$ after commencing the infusion. Blood was obtained by an indwelling i.v. cannula before and at 10,20,30, 45 and 60 min after the start of the infusion. Plasma CCK was measured by bioassay.

Mean (SEM) ejection fraction with the various IVAA regimens were: $61.0 \pm 12.5 \%$ with $250 \mathrm{ml}$ in $30 \mathrm{~min}, 76.8 \pm 6.5$ with $250 \mathrm{ml}$ in $10 \mathrm{~min}$, $63.6 \pm 8.4$ with $125 \mathrm{ml}$ in $5 \mathrm{~min}$, and $24.4 \pm 8.0$ with $50 \mathrm{ml}$ in $5 \mathrm{~min}$. The latter regimen produced significantly less emptying than the other three $(p<0.005)$. All IVAA regimens produced significant $(p<0.001)$ rise in plasma CCK concentrations. Peak and integrated plasma CCK concentrations were not different with infusions of $250 \mathrm{ml}$ in $30 \mathrm{~min}$ (mean $5.9 \pm 1.1 \mathrm{pmol} / \mathrm{l}, 211.3 \pm 32.2 \mathrm{pmol} / 1 / 60 \mathrm{~min}$, respectively) $250 \mathrm{ml}$ in $10 \mathrm{~min}(8.2 \pm 0.5,235.6 \pm 16.3), 125 \mathrm{ml}$ in $5 \mathrm{~min}(7.0 \pm 0.7,192.9 \pm 20.6)$, but were significantly lower with the infusion of $50 \mathrm{ml}$ in $5 \mathrm{~min}(2.1 \pm 0.2$, $82.4 \pm 6.3 ; p<0.001$ ).

Intermittent rapid infusion of IVAAs in a load as low as $125 \mathrm{ml}$ in $5 \mathrm{~min}$ promotes CCK release and gallbladder emptying and should prove useful therapeutically, not only during intravenous nutrition, but also in other situations associated with gallbladder inertia, such as critically ill patients in intensive care units and during the post-operative.

\section{OXIII/8 653}

OCTREOTIDE INCRRASES THE PROPORTIONS OF ARACHIDONIC ACID-RICH PBOSPHOLIPIDS IN GALLBLADDER BILE.

S.P. Pereira, S.H. Hussaini, T.B. Cassell, G.M. Murphy, J.A.H. Wass*, R.H. Dowling. Gastro Unit, Murphy, J.A.H. Wass ${ }^{*}$ R.H. Dowling. Gastro Unit, St Bartholomew's Hospital, London, England.

When used in the treatment of acromegaly, the somatostatin analogue, octreotide (OT), induces gallbladder stones (GBS) in 40-708 of patients. The usual explanation for these iatrogenic stones is that OT impairs GB motility, but we showed recently that $O T$ also induces lithogenic changes in biliary bile acid (BA) and cholesterol (CH) composition (Gut $199233(1)$ :S26; 33(2):S57). However, nothing is known about OT's -effects on biliary phospholipids (PLS) - of importance since increases
in arachidonic acid (20:4)-rich PLs (AAPLs) predispose to $\mathrm{CH}$ supersaturation and GBS formation. predispose to CH supersaturation and GBS formation. studied before and during 3 mo OT treatment (100 ug tds by SCI), we obtained samples of fresh GB bile by US-guided percutaneous fine-needle puncture, measured the molecular species of phosphatidylcholine (PC - the principal bitiary PL)-bY HPEC, and related the results to the relative proportions (moles?) of total BA, PL, and $\mathrm{CH}$ (measured enzymatically) and to the resultant $\mathrm{CH}$ saturation enzymatically) and to the resultant $\mathrm{CH}$ saturation
indices (CSIS). RESULTS: The relative proportions of the major PC molecular species, 16:0-18:2 and $16: 0-18: 1$, were similar before and during OT. However, PC $16: 0-20: 4$ (the predominant... AAPL) increased from $7.9 \pm$ SEM1.98 of total biliary PC $18: 0-20: 4$ rose from $0.4 \pm 0.2 \%$ to $1.0 \pm 0.2 \%$ ( $p<0.01)$. These changes in AAPL were associated with an increase in the CSI, from $0.89 \pm 0.08$ to $1.1 \pm 0.04$ increase in the CSI, from $0.89 \pm 0.08$ to $1.1 \pm 0.04$
$(p<0.05)$. SUMMARY: In acromegalic patients, OT increases the proportion of AAPLs in gallbladder increases the proportion of AAPLs in gallbladder CONCLUSIONS: These changes in PL composition are similar to those found in patients with CH GBS, and suggest that biliary AAPLs may also be important in the pathogenesis of OT-induced GBS. 